\title{
PERKEMBANGAN BENTUK KERAJINAN RENCONG DI DESA BAET KECAMATAN SUKA MAKMUR KABUPATEN ACEH BESAR
}

\author{
Saniman Andi Kafri ${ }^{*}$, Reza Sastra Wijaya ${ }^{2 *}$ \\ Program Studi Kriya Seni Jurusan Seni Rupa dan Desain \\ Institut Seni Budaya Indonesia (ISBI) Aceh \\ Jl. Transmigrasi, Gampong Bukit Meusara, Kec. Kota Jantho,Kab. Aceh Besar, Kode Pos 23911 \\ Aceh. Indonesia \\ Email: sanimanandikafri@isbiAceh.ac.id,rezasastrawijaya@isbiaceh.ac.id
}

\begin{abstract}
Abstrak
Rencong merupakan produk budaya lokal Aceh yang diwariskan secara turun-temurun oleh nenek mony angnya suku Aceh. Rencong sebagai s enjata tradisional sekaligus simbol identitas diri masy arakat Aceh memiliki sejarah panjang dan bentuk yang menarik. Sampai saat ini rencong Aceh tetap diminati oleh mas yarakat Aceh maupun pendatang yang berkunjung ke daerah Aceh. Seiring dengan berlakunya PSBB di Aceh, juga berdampak terhadap pengrajin rencong, Kondisi ini juga menuntut masyarakat harus mencari pekerjaan lain untuk dapat memenuhi kebutuhan hidup sehari-hari, dampak virus covid19 dirasakan langsung oleh pengrajin rencong yang ada di tiga desa Baet yaitu, Baet Masjid, Baet Lampuot dan Baet Meusago di kecamatan Sukamakmur Kabupaten Aceh Besar. Beberapa pen grajin yang bertahan, dikarenakan tidak adanya pekerjaan lain seperti yang dilakukan oleh bapak Yudi Hidayat, Ibrahin danZuhri. Pemerintah Aceh bahkan telah menetapkan kampung-kampung ini sebagai kampung rencong yang menjadi destinasi wis ata baru di Aceh. Sebelum Covid - 19 hampir semua penduduknyaberpropesi sebagai pengrajin rencong. Membuat rencong dilakukan secara turun-temunun dimana pembuatan kerajinan ini dilakukan oleh laki-laki dan perempuan. Keunikan rencong dapat dilihat dari bentuknya yang menyerupai kalimat Bismillah ditulis dalam bahasa Arab. Hal ini menunjukkan adanya hubungan erat antara rencong dengan Is lam. Perubahan zaman tentunya turut mengubah kebudayaan, dalam hal ini turut merubah bentuk rencong dan fungsi rencong itu sendin, dimana dahulunya bentuk rencong hanyaberukuran $35 \mathrm{~cm}$ dan dalamperkembanganya bentuk rencong saat ini sudah mulai ber pariasi mulai dari ukuran $15 \mathrm{~cm}$ sampai dengan $2 \mathrm{M}$, selain itu rencong pada saat ini produksi lebih memanfaatkan pamor rencong sebagai salah satu senjatakhas Aceh yang ada di Indonesia sehingga fungsinya beralih dari fungsi praktis menjadi fungsi estetis sehingga tujuan produksinya turut mempengaruhinya, dimana rencong saat ini sudah digunakan sebagai aksesoris dalam pakaian adat Aceh dan aksesoris dalam pagelaran pertunjukan. Metode penelitian "Perkembangan Bentuk Kerajinan Rencong di Desa Baet Kecamatan Suka Makmur Kabupaten Aceh Besar" ini dilakukan dengan menggunakan penelitian kualitatif. Metode ini dapat menjawab semua rumusan masalah dalam penelitian ini. metode kualitatif juga dapat menggali informasi secara mendalam.
\end{abstract}

Kata Kunci: rencong, kerajinan, fungsi estetis .

\begin{abstract}
Rencong is a product of local Aceh culture that has been passed down from generation to generation by his Acehnese mony grandmother. Rencong as a traditional weapon as well as a symbol of Acehnese identity has a long history and an interesting form. Until now, Aceh rencong is still in demand by Acehnese people and migrants visiting the area. Along with the enactment of the Large-Scale Social Restrictions in Aceh it also has an impact on rencong craftsmen, this condition also requires people to find other jobs to be able to meet their daily needs, the impact of the covid-19 virus is felt directly by rencong craftsmen in three Baet villages, namely, Baet Masjid, Baet Lampuot and Baet Meusago in Sukamakmur sub-district, Aceh Besar district. Some of the craftsmen who survived, were due to the absence of other jobs such as those done by Yudi Hidayat, Ibrahin and Zuhri. In this case, the Aceh government has even designated these villages as Rencong villages which have become new tourist destinations in Aceh. Almost all residents work as rencong craftsmen. Making rencong has been done from generation to generation. The making of this craft is done by both men and women. The uniqueness of rencong can be seen from its shape which resembles the sentence Bismillah written in Arabic. This shows the close relationship between rencong and Islam. Changes in time have certainly changed the culture, in this case also changing the shape of the rencong and the function of the rencong itself, where previously the shape of the rencong was only $35 \mathrm{~cm}$ in size and in its development the shape of the rencong now varies from $15 \mathrm{~cm}$ to $2 M$ in size, besides The current rencong production utilizes the prestige ofrencong as one of Aceh's typical weapons in Indonesia so that its function is shifted from a
\end{abstract}




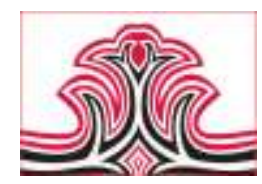

Gorga : Jurnal Seni Rupa

practical function to an aesthetic function so that its production objectives also influence, where rencong is currently used as an accessory in Acehnese traditional clothing and accessories in performances the research method "Development of Rencong Craft Forms in Baet Village, Suka Makmur District, Aceh BesarDistrict. "This isdone using qualitative research. This method can answer all problem formulations in this study. Qualitative methods can also digging information.

Keywords: rencong, craft, aesthetic function..

\section{PENDAHULUAN}

Rencong adalah salah satu bentuk materil yang lahir dari budaya Aceh yang memiliki fungsi-fungsi ters en diri di tengah mas yarakat, yakni berfungsi s ebagai simbol status sosial, sebagai alat perhias an sehari-hari oleh pria-pria Aceh dalam gerak kehidupannya, s ebagai perkakas, Sebagai pemberian kepada para pengunjung atau tamu-tamu daerah sebagai tanda penghormatandan sebagai senjata andalan masyarakat Aceh terhadap ancaman dari luar. Rencong juga digunakan sebagai senjata dalam melawan para penjajah yang mas uk ke daerah Aceh.

Reuncong atau Rencong merupakan senjata tradis ional milik suku Aceh. Rencong meru pakan simbol indentitas diri, keberanian, dan ketangguhan suku Aceh. Rencong juga sebagai senjata tradisional yang digunakan Kesultanan Aceh sejak masa pemerintahan Sultan Ali Mughayat Syah (Said, 1981: 157). Kedudukan Rencong di kesultanan Aceh sangat penting sehingga dikala itu rencong selalu diselipkan dipinggang Sultan Aceh, para ulee balang (Pememimpin sebuah daerah) dan masy arakat. Salah satu daerah y ang masih meles tarikan pembuatan rencong sampai saat ini adalah desa Baet yang terletak di kecamatan Sukamakmu kabupaten Aceh Besar.

Produkyang dihasilkan di desaBaet yaitu rencong yang terdiri dari tiga jenis, rencong mecunggek, rencong pudoi dan rencong meukuree. Di desa Baet pembuatan rencong dilakukan sebagai produksi cinderamata yakni dengan menambahkan figura serta berbagai aksesoris serta ornament pada sarung dan gagang rencong tersebut. Hal ini membuktikan bahwasanya adanya perges eran tujuan dari penciptaan rencong yang mana tujuan utama pembuatan rencong sebagai senjata andalan masyarakat Aceh berubah fungsi menjadi simbol kebudayaan Aceh (Wawancara, Yudi, Juli 2020). Rencong sebagai salah satu senjata tradisional Aceh yang dianggap bertuah, tidak sembarangan dalam proses pembuatannya. Pembuatan sebilah Rencong menyerupaitulis an Bismillah dengan nama Allah dalam bentuk aksara Arab (Sri Waryanti, 2013: 403). Penjelasan diatas menunjukkan adanya hubungan erat antara rencong dengan nuansa Is lam. Hal ini tentu berbeda dengan kondisi saat ini, dimana rencong dibuat dengan mudah tanpa harus menunggu waktu yang lama, selain itu rencong juga sudah dijadikan sebagai cendramata, yang dapat dimiliki oleh siapa saja.

Rencong sebagai senjata khas Aceh tetap diminati sebagai koleksi dan kebangaan bagi pemegangnya sehingga para perajin terus memproduksi benda kebanggaan mas yarakat Aceh ini. Terutama bagi perajin rencong yang ada di tiga kampung Baet yaitu, Baet Masjid, Baet Lampuot dan Baet Meusago di kecamatan Sukamakmur Kabupaten Aceh Bes ar. Pengrajin selalu aktif dalam memproduksi rencong sehingga rencong Aceh masih bertahan sampai saat ini. Hampir semua penduduknya desa Baet berprofesi sebagai pengrajin rencong bahkan pembuatan rencong sudah dilakukan secara turun-temurun.

Sangat disayangkan dengan berlakunya PSBB di Aceh memberikan dampak terhadap pengrajin rencong di desa Baet, hal ini dirasakan langsung oleh para pengrajin dengan menurunya jumlah pesanan. Kondisi ini juga menuntut masyarakat desa Baet harus mencari pekerjaan lain untuk dapat memenuhi kebutuhan hidup mereka, dampak vinus covid-19 diras akan langsung oleh mas yarakat terutama bagi perajin rencong y ang ada di tiga kampung Baet yaitu, Baet Masjid, Baet Lampuot dan Baet Meusago di kecamatan Sukamakmur Kabupaten Aceh Besar.

Umumnya para pengrajin tidak menjual hasil kary anya sendiri, namun para pengrajin mendistribusikan melalui agen dan dipasarkan ke toko-toko souvenir Aceh yang ada di Banda Aceh dan Sekitarnya (Wawancara, Yudi Juli 2020). Perkembangan zaman turut mempenganuhi rencong dalam kebudayaan Aceh, terutama fungsi dari rencong itu sendiri. Produksi rencong sebagai senjata tentu sudah tidak relevan dengan kondisi Aceh pada saat ini. Dengan demikian rencong tetap menjadi primadona bagi berbagai kalangan masyarakat yang berkunjung ke Aceh tentunya dengan rencong yang beralih fungsi dari senjata menjadi cinderamata ataupun hadiah kehormatan bagi tamu istimewa dari luar Aceh. Perubahan persepsi terhad ap rencong ini yang menjadi day a tarik untuk dilakukan sebuah riset yang mendalam agar dapat menepis berbagai persepsi yang simpang siur mengenai eksistensi rencong pada masa sekarang. Selain itu penelitian ini juga bertujuan melihat sejauh mana perkembangan bentuk dan fungsi rencong dalam kehidupan masyarakat. 


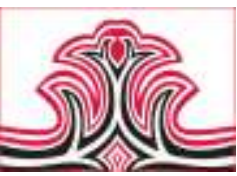

Berdasarkan dari uraian diatas dapat kita rumuskan, rumusan masalah dalam penelitian ini, bagaimana perkembangan bentuk rencong di desa Baet dan bagaimana perkembangan fungsi rencong di des a Baet. Adapun tujuan dilakukanya penelitian Perkembangan bentuk rencong di desa Baet kecamatan Sukamakmur kabupaten Aceh Bes ar ini adalah guna mengetahui dan mendes kripsikan perkembangan bentuk rencong di desa Baet. Mengetahui sejauh mana pergeseran nilai fungsi rencong di desa Baet. manfaat dari dilakukanya penelitian ini diantaranya seperti menambah wawasan masyarakat mengenai rencong di desa Baet. Sebagai refrensi selanjutnya untuk peneliti yang ingin membahas tentang rencong di desa Baet. Sebagai upaya untuk melestarikan dan pengembangan dalam industri kerajinan.

\section{KAJIAN TEORI}

\section{Teori Bentuk}

Teori yang digunakan dalam menganalisis perkembangan bentuk rencong di desa Baet ini menggunakan teori bentuk, karena yang dilihat adalah bagaimana bentuk perkembangan.

"Bentuk (form) adalah totalitas daripada karya seni. Bentuk itu merupakan organisasi atau satu kesatuan, komposisi dari unsur-unsur pendudukung karya. Ada dua macam bentuk: Visual form, yaitu bentuk fisik dari sebuah kary a seni atau kesatuan dari unsur-unsur pendukung karya seni tersebut. Special form, yaitu bentuk y ang diciptakan karena adanya hubung an timbal balik antara nilai-nilai yang dipancarkan oleh fenomena bentuk fiksinya terhadap tanggapan kesadaran emasional" (Dharsono, 2016:8-9).

Menurut teori diatas, seni dilihat dari bentuk sebagai sus unan elemen-elemen seni yang mempunyai makna. Seperti bentuk rencong merupakan unsur dari seni rupa dan kriya. Bentuk fisik dapat dilihat dari unsur garis yang memiliki peran penting untuk memberi tandadari bentuk logis pada rencong dan berperan sebagai lambang yang mengambarkan sesuatu yang mewakili atau mempunyai eks presi dari seorang seniman.

\section{Teori Fungsi}

Teori fungsi berupaya memudahkan dalam menganalisis dan menjawab permas alahan fungsi digunakan teori fungsi yang dikemukakan Edmund Burke Feldman terjemahan Sp Gustami dimana fungsi dibagi atas tiga fungsi seni yaitu: (the personal function of art) fungsi personal, (the social function of art) sosial, dan (the fhysical function of art). 1) fungsi personal yaitu kebutuhan-kebutuhan tentang ekspresi pribadi, 2) fungsi sosial yaitu kebutuhankebutuhan sosial untuk keperluan hiasan, dan 3) fungsi fisik kebutuhan-kebutuhan fisik mengenai barang-barang dan
Gorga : Jurnal Seni Rupa

Volume 09 Nomor 02 Juli-Desember 2020

p-ISSN: 2301-5942 | e-ISSN: 2580-2380

bangunan-bangunan yang bermanfaat (Feldman,1967: 4). Fungsi selalu menjadi pertimbangan dalam sebuah karya seni fungsional selain dari bentuk yang akan dihasilkan, sehingga bentuk yang sederhana akan terasa penting apabila fungsinya sesuai dengan keinginan pengamat. Teori fungsi ini dimanfaatkan untuk mengurai as pek fungsi yang terdapat pada bentuk rencong di desa Baet.

\section{METODE PENELITIAN}

Penelitian "Perkembangan Bentuk Kerajinan Rencong Di Desa Baet Kecamatan Sukamakmur Kabupaten Aceh Besar" peneliti menggunkan metode penelitian kualitatif, karena dengan metode kulaitatif ini peneliti mampu menguraikan dan sekaligus mampu menjawab dari rumusan masalah yang ada. Selain itu metode ini juga dianggap relevan karena mampu menggali lebih dalam informasi sesuai dengan yang dibutuhkan oleh peneliti. Adapun Langkah-langkah yang akan dilakukan dalampenelitian ini yaitu:

\section{Studi Pustaka}

Studi pustaka yang sudah dilakukan diantaranya seperti ke perpustakaan daerah dan perpustakaan pusat Ins titut Seni Budaya Indonesia Aceh. Studi ini dilakukan untuk mengumpulakan data yang berkaitan dengan penelitian sehingga tidak terjadi plagiat dalam penulisan. Studi pustaka juga dilakukan gunamembantu melengkapi tulisan ini dimana tulis an padabuku tersebut dapat dijadikan salah satu acuan sekaligus pembanding dalam menyempurnakan tulis an ini.

\section{Observasi}

Metode observasi dalampenelitian seni dilaksanakan untuk memperoleh data tentang karya seni dalam suatu kegiatan dan situasi yang relevan dengan masalah penelitian. Observasi dapat berlansung dari catatan tentang karya seni yang diamati berkaitan dengan baik tingkah laku yang sangat terstruktur dan terinci maupun gambaran peristiwa dan tingkah laku yang ambigu (Rohendi,2011,182).

Observasi ini dilakukan untuk melihat secara langsung pros es kerajinan rencong kerajinan di desa Baet Kecamatan Suka Makmur Kabupaten Aceh Besar sebagai objek penelitian. Observasi juga dibutuhkan kejelian dan perhatian khusus untuk melihat objek agar tidak terjadi kesalahan dalam menafsirkannya. Observasi ini juga bertujuan untuk megumpulkan data - data selengkap mungkin dan semua hal yang penting. Observasi menjdi s alah satu langkah yang tepat dalammelakukan sebuah riset atau peneitian.

\section{Wawancara}

Wawancara adalah suatu teknik yang digunakan untuk memperoleh informasi tentang kejadian yang oleh peneliti tidak dapat diamati sendiri sevara langsung, baik karena 


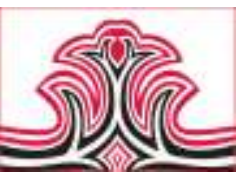

tindakan atau peristuiwa yang terjadi dimasa lampau ataupun karena peneliti tidak diperbolehkan hadir ditempat kejadian itu (Rohendi,2011:208). Teknik ini dilakukan untuk mencari data yang tidak dapat dicapai dengan pengamatan, dalam upaya memperoleh data, penulis melakukan wawancara dengan informan. Informan yang diwawancara harus yang mengerti dan paham terhadap objek yang diteliti. Alat untuk mendukung penelitian ini meggunakan handphone (HP) untuk merekam suara, Camera untuk mengambil gambar dan merekam video. Adapun narasumber yang sudah dilakukan proses wawancara sebanyak lima orang narasumber mulai dari pengrajin dan para agen yang menampung kerajinan rencong.

\section{Analisis Data}

Analisis mrupakan proses penggalian dan pendalaman terhadap keakuratan data-data yang sudah di dapatkan. Kemudian analisis data dilakukan sesudah pengumpulan data mulai dari hasil studi pustaka, observasi dan wawancara. Data dari hasil studi pustaka, observasi dan wawancara dipisahkan dan di kelompokkan sehingga datadata yang diperoleh dapat dianalisis atau dipahami untuk mengetahui kerajinan Rencong di Desa Baet Kecamatan Sukamakmur Kabupaten Aceh Besar. Menurut Miles dan Hubermen dalambuku MetodelogiPenelitian menjelaskan, pengumpulan data sebagai proses pertama dilakukan melalui berbagai cara, seperti observasi, wawancara, rekaman, dokumen, simulasi dan sebagainya yang secara keseluruhan merupakan kata-kata. Proses kedua dimaksudkan sebagai penyederhanaan data sehingga lebih mudah untuk di analisis. Proses ketiga adalah deskripsi ters truktur yang memungkinkan untuk melakukan proses keempat, yaitu mengambil simpulan itu sendini. (Ratna,2010:310).

Analisis data pada kerajinan rencong di Desa Baet sangat diperlukan untuk membuktikan dengan akurat sumber data yang sudah dikumpulkan. Tahapan dimulai dengan melakukan pencairan data, mempelajari dan mengelompokkan data sehingga memperoleh kesimpulan data menjadi lebih valid. Proses ini dibutuhkan untuk mengkaji proses dan produk kerajinan rencong pada desa Baet Kecamatan Sukamakmur Kabupaten Aceh Besar.

Kerajinan rencong sebagai waris an budaya Aceh yang kuat dan memiliki nilai luhur budaya Aceh yang kental dengan nilai-nilai keislaman, maka rencong perlu direvitalisasi melalui berbagai upaya, salah satu upaya yang dilakukan oleh mas yarakat yakni dengan tetap memproduksi rencong dengan tujuan produksi yang beralih fungsi, yakni dari fungsi sebagai senjata menjadi cenderamata ataupun sebagai s ymbol dalam berbagai kegiatan adat Aceh. Dari pengamatan terhadap berbagai isu dan sumber, rencong
Gorga : Jurnal Seni Rupa

Volume 09 Nomor 02 Juli-Desember 2020

p-ISSN: 2301-5942 | e-ISSN: 2580-2380

diketahui telah berubah fungsi yakni dari fungsi praktis menjadi fungsi estetis. Fungsi ters ebut dipengaruhi oleh relevansi zaman.

\section{Diagram Alur Penelitian}

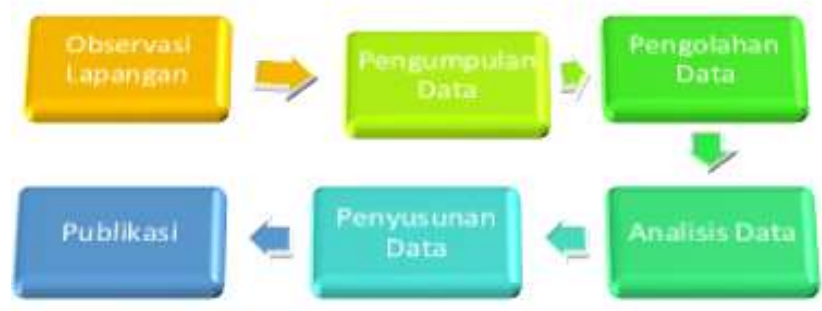

Gambar 1. Bagan Alur Penelitian (Sumber: Saniman Andi Kafri, 2020)

\section{HASIL DAN PEMBAHASAN}

\section{Hasil}

\section{1). Desa Baet}

Desa Baet merupakan salah satu desa yang terdapat di kecamatan Suka Makmur dan berada di Aceh Bes ar. Desa Baet merupakan daerah satu-satunya di Aceh Besar yang manyoritas masyarakatnya bekarja sebagai pengrajin rencong. Pembuatan kerajinan rencong tidak hanya digeluti oleh kaum laki-laki saja melainkan kaum wanita juga terlibat dalam pembuatan rencong, terutapa pada proses pengilatan/penghalusan rencong. Penduduk desa Baet manyoritas nya penganut agama Is lam, agama yang sudah dianut secara turun temurun. Pada desa Baet saat ini ada tiga desa yang masih berperan aktif dalam pembuatan rencong seperti desa Baet Mesjit, Baet Lampuot dan Baet Meusago.

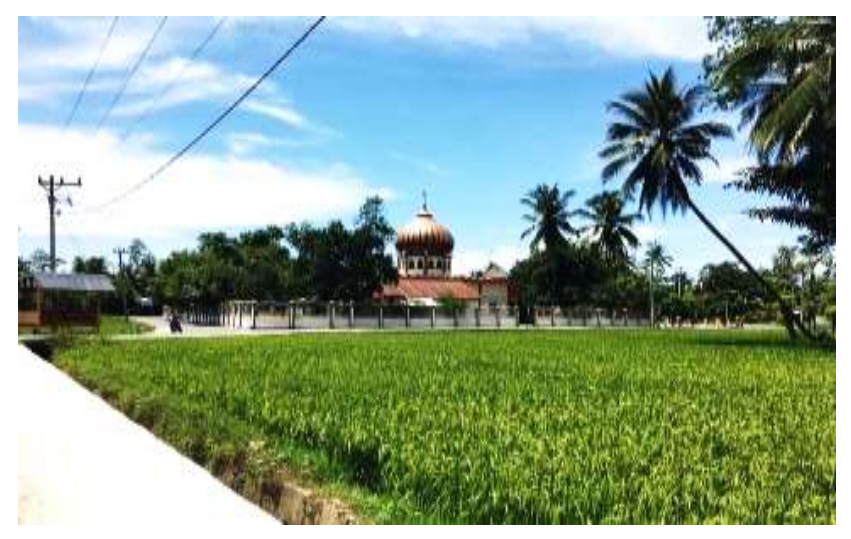

Gambar 2. Suasana Desa Baet (Sumber: Saniman Andi Kafri, 2020)

Des a Baet juga dikelilingi oleh daerah pers awahan dimana masyarakatnya, selain memproduksi kerajinan rencong juga bekerja sebagai petani. Masyarakat desa Baet memiliki satu buah masjid yang terletak di des a Baet Masjid dimana masjid ini sebagai penghubung dari ketiga buah desa Baet ini. Sebagai yang sudah dinobatkan sebagai kota wisata oleh pemerintah daerah Aceh dimana, desa Baet menjadi 


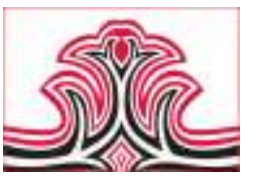

desa penghasil kerajinan rencong terbanyak di Aceh (Wawancara, Abdul Juli 2020).

\section{2). Rencong}

Rencong sebagai senjata tradisional Aceh memiliki hubungan yang sangat erat dengan kebudayaan Islam. Keterkaitan rencong dengan kebudayaan Islam sangat tinggi, karena dilihat dari sejarah pembuatan rencong yang dibuat langsung oleh seorang pemangku agama. Yudi menjelas kamProses pembuatan rencong itu sendiri melalui proses ritual yang sehingga dinilai memiliki unsur-unsur magis . pada dahulunya proses pembuatan rencong ini tidak secepat pembuatan rencong yang ada pada mas a sekarang. Rencong yang dibuat pada zaman dahulu dibuat secara bertahap dengan ketelitian dan kerumitan yang sangat tinggi sehingga memakan waktu yang cukup lama dalam proses pembuatannya. sebelum dilakukan pembuatan rencong dilakukan ritual keagamaan seperti melakukan dzikir (meratif) Hal ini bertujuan untuk meraih keridhaan oleh Allah subhanahu wa ta'ala agar benda yang dibuat memberikan banyak manfaat dan memberikan berkah bagi masyarakat Aceh (Wawancara, Yudi, Juli 2020).

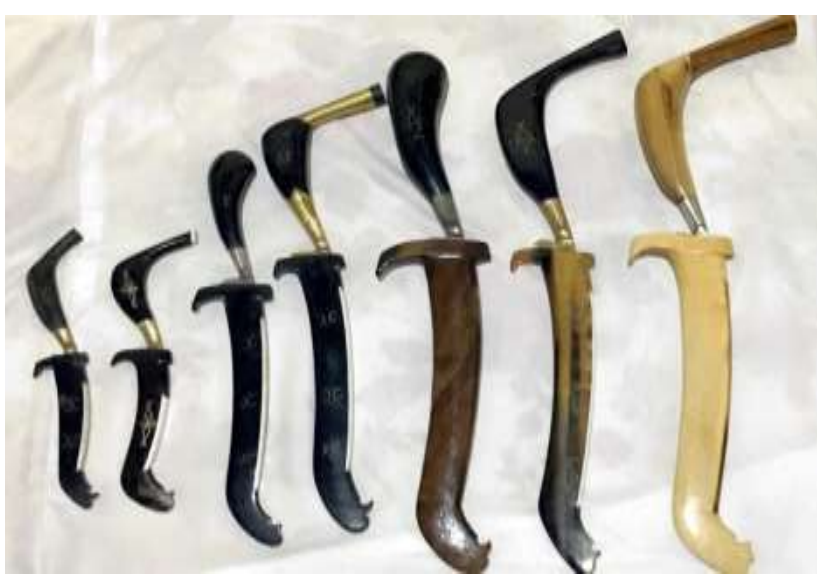

Gambar 3. Bentuk Rencong

(Sumber: Saniman Andi Kafri, 2020)

Rencong merupakan simbol dari eksistensi kebudayaan masyarakat Aceh, karena dianggap memiliki sejarah yang panjang dalam meraih kemerdekaan Aceh melawan penjajahan belanda. selain itu dahulunya masy arakat Aceh juga menganggap rencong memiliki nilai estetika dan magis yang tinggi. Rencong adalah salah satu bentuk senjata tradisional khas Aceh yang memiliki bentuk yang s angat unik, sehingga senjata ini tidak mirip atau tidak sama dengan senjata-senjata tradisional di daerah lain. Bentuk rencong yang unik terdapat pada bentuk anatomi senjataitu sendiri yang dibuat dengan lengkungan yang sangat elegan mulai dari ujung bilah s enjata sampai ke gagangnya. Secara umum bentuk senjata rencong ini menyerupai bentuk kalimat yang ada di dalam Alqur'an yakni bentuk Bismillah. Rencong juga merupakan identitas diri
Gorga : Jurnal Seni Rupa

Volume 09 Nomor 02 Juli-Desember 2020

p-ISSN: 2301-5942 | e-ISSN: 2580-2380

masyarakat yang merupakan simbol keberanian, ketangkasan masyarakat Aceh.

"Rencong sendiri sudah digunakan semenjak masa Sultan 'Ali Mughayat Syah, yang memerintah kesultanan Aceh pada abad ke 16" (Wawancara, Mahdi, Agustus 2020), rencong sebagai senjata tradisional Aceh memiliki bentuk yang berbeda senjata tradional masyarakat Aceh lainya yakni suku Gayo, Alas, Singkil dan Aceh lainya, senjata rencong jugahanya digunakan oleh masyarakat suku Aceh yang manyoritasny a tinggal didaerah pesisir pantai seperti, Banda Aceh, Aceh Besar, Sigli, Pidie, Bireun, Lhokseumawe dan beberapa daerah lainya. Sedangkan mas yaraka Aceh yang berbeda suku menggunakan senjata tradisional yang berbeda.

\section{3). Kerajinan Rencong Mulai Populer di Desa Baet}

Rencong sebagai senjata tajam sudah menjadi prodak yang dikenal di daerah Aceh, dimana rencong memiliki bentuk yang unik, berbeda dengan bentuk senjata tajam di daerah lainya. salain itu rencong juga digunakan oleh para tokohtokoh masyarakat sesuai dengan strata dan bentuk rencongnya. Rencong sebagai prodak budaya local sangat mudah diterima oleh masyarakat dikarenakan memiliki nilai historis yang tinggi.

"Kerajinan rencong sudah ada semenjak abad ke 16, dan kerajinan rencong mulai dikenal oleh masyarakat Aceh sebagai senjata tajam. Rencong sendiri mulai berkembang dan populer setelah pasca tsunami pada tahun 2004. Di tahun Sembilan puluhan, rencong belum begitu dikenal oleh masyarakat luas. Pada tahun 2015 juga desa rencong dinobatkan sebagai desa wisata Aceh oleh pemerintah Aceh, namun s angat dis ayangkan deng an kondisi covid-19 masyarakat Baet khususnya para pengrajin rencong belum ada menerima bantuan dari pemerintah Aceh." (W awancara, Yudi, 26 Juli 2020).

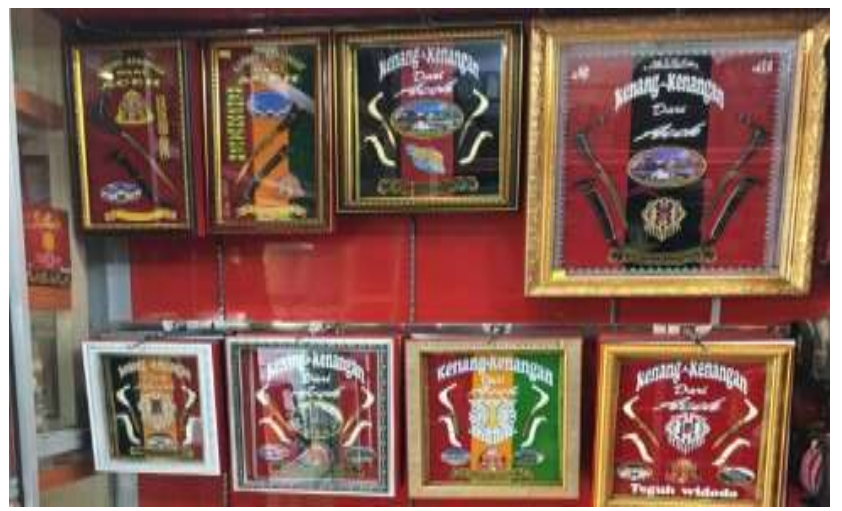

Gambar 4. Souvenir Rencong

(Sumber: Saniman Andi Kafri, 2020)

Kerajinan souvenir rencong berkembang sangatpesat mu lai tahun 2004 sesudah tsunami melanda Aceh. dengan 


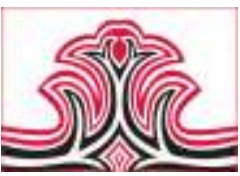

banyaknya pengunjung Aceh pasca ts unami yakni relawan dari berbagai penjuru tanah air bahkan dari luar negen melirik benda unik, sehing ga menarik perhatian mereka. pada saat itu juga rencong banyak diminati karena keunikannya sehingga jumlah permintaan akan suvenir ini meningkat secara drastis. Produksi rencong juga di pasarkan dibeberapa daerah seperti di Banda Aceh, Lhokseumawe, Sigli, Bireun, Langsa, Medan. Selain itu rencong juga sudah dipasarkan s ampai ke luar negri seperti Malaysia dan negara tetangga lainya.

Sejauh ini dapat kita lihat bahwa rencong sebagai senjata tradisi Aceh sudah dikenal dalamnegeri maupun di negeri tetangga. Namun sangat disayangkan bahwa kondisi s aat ini banyak sekali pengrajin rencong terpaksa berhenti memproduksi rencong karena menurunya jumlah pesanan rencoang. Situasi dunia yang sedang mencekam yang diselimuti oleh pandemi covid- 19 memaksa pengrajin harus menghentikan aktivitasnya disebabkan menununnya permintaan prsanan rencong. Pembatas an sosial bers kala bes ar setiap penjuru dunia memaks a sektor pariwisata harus ditutup untuk sementara waktu. Kondisi ini tidak hanya terjadi di Indonesia saja namun juga terjadi diseluruh penjuru dunia yang terdampak. hal ini mengakibatkan pusat distribusi rencong juga ikut terhenti.

\section{4).Perbedaan Rencong di Desa Baet dengan Daerah lainnya}

Adapun perbedaan rencong di desa Baet dengan daerah lainya adalah berupa bentuk anatomi Rencong yang berbeda dengan as linya. pada umumnya bentuk rencong di daerah Baet lebih rapi dan bersih dibandingkan didaerah lainya, dari segi pembuatan gagang dan sarung rencong hanya daerah Baet yang menjadi distributor produksi. selain itu produksididesa Baet juga sudah memiliki pengalaman dan memiliki nama baik dimata masyarakat sebagai tempat produksi perdana atau yang sudah diakui oleh mas yarakat.

Rencong yang terdapat di daerah Aceh lainnya merupakan rencong yang dipelajari dari desa Baet dan kemudian dikembangkan seperti rencong yang terdapat di daerah Langsa dan Bireuen. Hal ini dikarenakan rencong yang paling asli dan original hanya dibuat di desa Baet berusia s angat lama dan diwariskan secara turun-temurun. Adapun us aha yang dilakukan oleh pengrajin di daerah lain tentunya tidak dapat seindah dan sebagus yang dibuat oleh masyarakat desa Baet. Hal ini ditandai dari kerapian dan kerumitan bentuk rencong pada proses produksi.

Selain pembuatan rencong yang dibuat dalambentuk yang konvensional desa ini juga memproduksi berbagai bendabenda tajam seperti pis au dapur, parang dan jenis senjata pes anan lainnya yang dibuat sesuai deng an pesanan. Selain itu juga dikembangkan jenis-jenis senjata lainya yang
Gorga : Jurnal Seni Rupa

Volume 09 Nomor 02 Juli-Desember 2020

p-ISSN: 2301-5942 | e-ISSN: 2580-2380

berbentuk selain rencong seperti senjata siwa' yang digunakan dalam upacara adat dan khusus digunakan oleh pemimpin Aceh atau Sultan.

\section{5). Pengrajin Rencong di Desa Baet}

Senjata tradisional Aceh merupakan benda tajam yang dimiliki oleh Aceh sekaligus merupakan senjata khas Aceh merupakan produksi dari satu daerah yang berada di provinsi Aceh yakni tepatnya di kabupaten Aceh Besar. Daerah yang memproduksi rencong ini beradadi desa Baet kecamatan Sukamakmur Kabupaten Aceh Besar. Dahulunya desaini adalah satu kawasan pen grajin rencong terbesar ditanah Aceh. Namun setelah dilakukannya pemekaran maka desa ini dibagi menjadi tiga bagian yakni desa Baet Masjid, Baet Lampuot dan Baet Meusago.

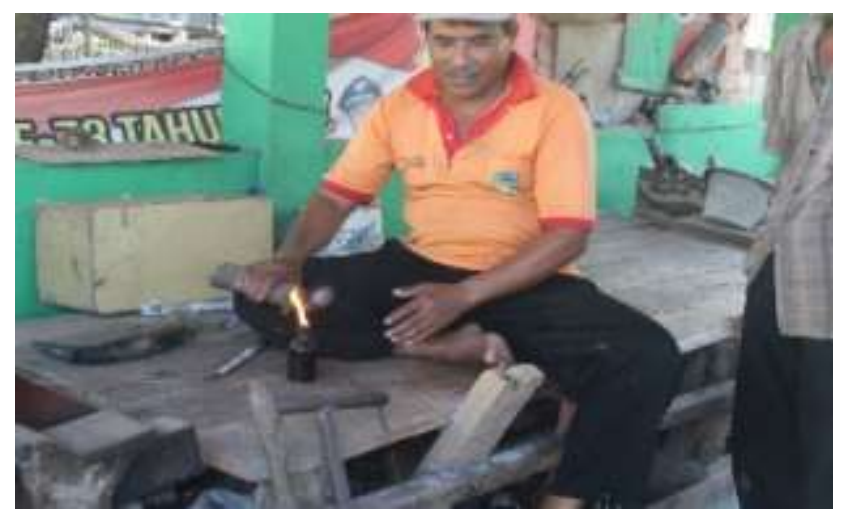

Gambar 5. Wawancara dengan Mahdi Pengrajin Rencong (Sumber: Reza Sastra Wijaya, 2020)

Selain berprofesi sebagai petani dan peternak keselumhan masyarakat desa Baet pada mulanya berprofesi sebagai pengrajin rencong yakni deng an perannya masing-masing. Dimulai dari pencari logam, pencari bahan tanduk kerbau, pencari material kayu dan material material lainnya yang dapat dipergunakan sebagai bahan baku pembuatan rencong. Profesi tersebut dilakukan oleh masing-masing mas yarakat y ang ada di desa Baet tersebut dengan perannya masing-masing. Setelah seluruh material-material terkumpul maka bahan-bahan mentah tersebut didistribusikan ke masing-masing pengrajin lain yakni diantaranya ada sebagai pengecor logam, pengasah bilah, pengrajin tanduk sehingga pengrajin tangkai dan sarung. Masing-masing pengrajin ters ebut menjalankan perannya hingga komponen ters ebut tersebut nantinya digabungkan oleh satu pengrajin lainnya. Proses ini memakan waktu yang cukup lama sebab pembuatan rencong ini masih menggunakan cara-cara yang tradisional. 


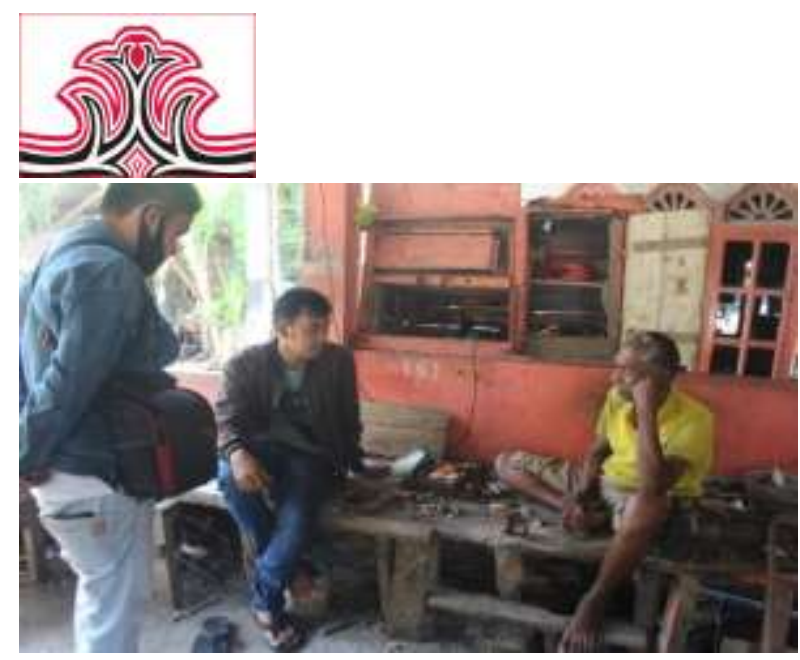

Gambar 6. Wawancara dengan Zuhri Pengrajin Rencong (Sumber: Siti, 2020)

"Kemampuan pembuatan kerajinan rencong didapat oleh masyarakat di desa ini hampir tidak dapat ditemukan awal mulanya sebab kerajinan ini dilakukan sudah secara turun-temurun oleh nenek moyang orang Aceh bahkan sebelum masa kolonialisme Belanda" (Wawancara, Zuhri, Agustus 2020).

Teknik pembuatan rencong ini sangat unik, yakni dengan memberikan pengetahuan pembuatan rencong kepada pemuda-pemudinya secara bertahap. Dimulai dengan memberikan pekerjaan yang ringan-ringan namun tetap mengamati pekerjaan rumit yang dilakukan oleh pengrajin rencong yang sudah profesional. Setelah dianggap mampu pengrajin rencong yang pemula baru membuat rencong pada tingkatan yang lebih rumit seperti pada tahap pembuatan gagang, sarung rencong sampai pada tahapan finishing.

Pengrajin yang aktif di desa Baet ini mayoritasnya adalah laki-laki mulai usia 16 tahun hingga orang tua. Dalam kondisi yang aktif dalam sehari seorang pengrajin dapat menghasilkan lima sampai tujuh buah rencong dalam sehari. Semenjak diterapkanya peraturan PSBB di Aceh, menjadi salah satu pemicu menurunnya prekonomian masyarakat di Aceh dan salah satu desa yang terkena dampaknya adalah desa Baet dikarenakan minimnya jumlah pesanan lokal maupun pesanan luar, sehingga beberapa warg a terpaks a beralih propesi dari pengrajin rencong menjadi petani dan buruh harian lepas.

\section{Pembahasan}

\section{1). Perkembangan Proses Pembuatan Rencong}

Pembuatan rencong dilakukan secara bertahap yakni dimulai dengan pengolahan bahan baku utama benupa pengolahan logam yang dikumpulkan dari berbagai material yang tidak terpakai atau dari material bekas seperti material komponen-komponen kecil dari mobil, sepeda motor, dan bahan logam lainya yang sudah tidak terpakai lagi. "Bahan-bahan material ini didapatkan dari dis tributor barang-barang bekas. Lalu kemudian komponen itu yang
Gorga : Jurnal Seni Rupa

Volume 09 Nomor 02 Juli-Desember 2020

p-ISSN: 2301-5942 | e-ISSN: 2580-2380

sudah dibeli dilebur dengan menggunakan tungku peleburan logam dengan suhu tertentu sehingga logamlogam tersebut dapat dilelehkan menjadi logam cair. Kemudian logam cair dituang ke dalam cetakan sehingga membentuk bilah rencong yang sudah mirip dengan cetakan sebelumnya, hanya menunggu beberapa detik saja cetakan rencong ini akan jadi” (Wawancara, Ibrahim, 7 Agustus 2020).

Pembuatan rencong saat ini lebih mudah dan lebih cepat dikarenakan pembuatanya dengan cara di cetak. Berbeda dengan pembuatan rencong pada zaman dahulu dimana rencong dibuat dengan cara ditempa. Perkembangan ini membuat pengrajin dapat menghasilkan jumlah rencong yang lebih banyak.

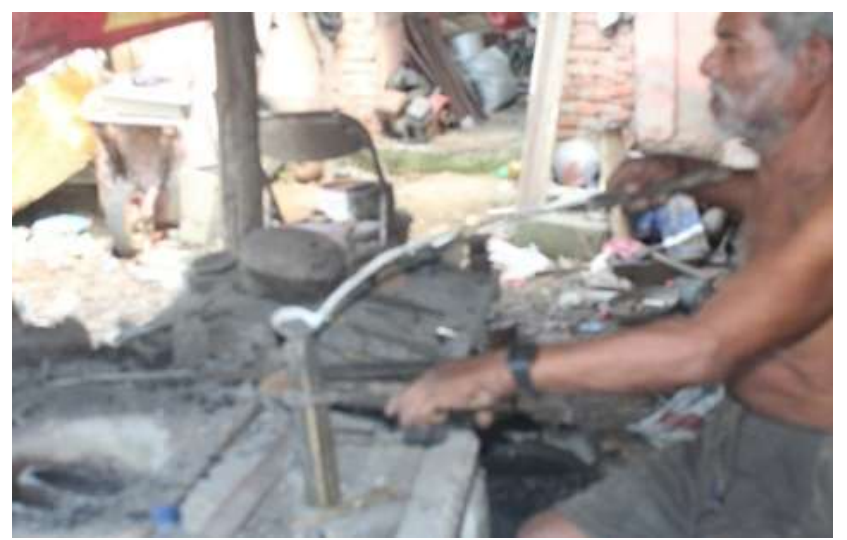

Gambar 7. Proses Pencetakan Besi Rencong oleh Ibrahim (Sumber: Siti, 2020)

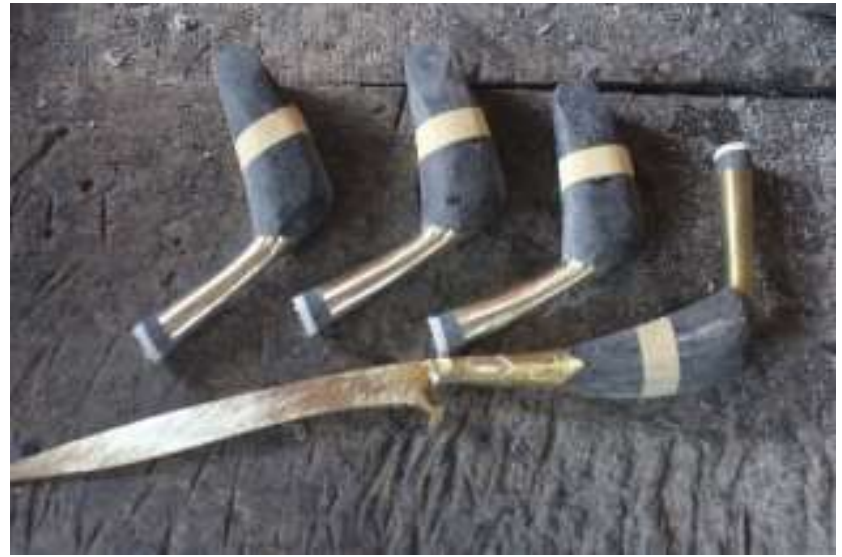

Gambar 8. Proses Pembuatan Gagang Rencong (Sumber: Saniman Andi Kafri, 2020) 


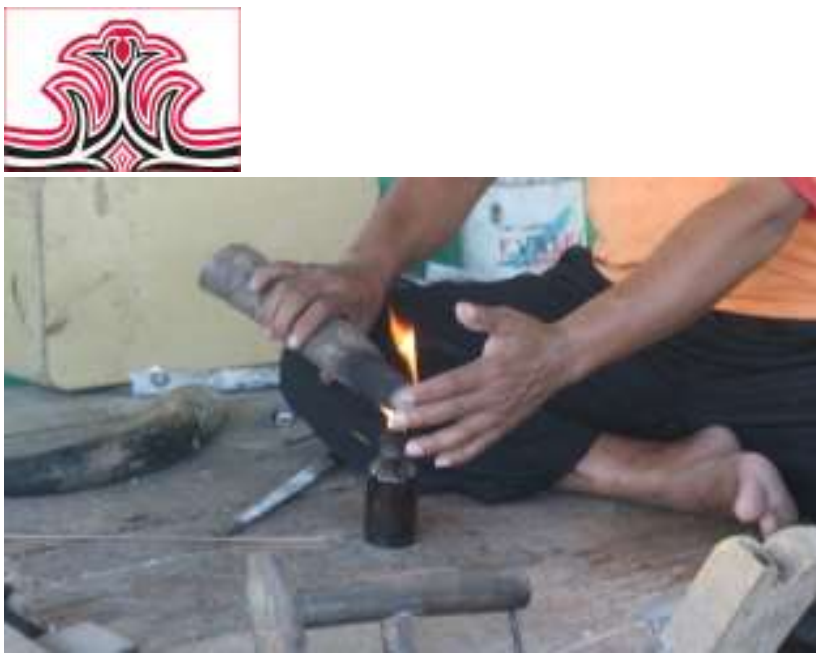

Gambar 9. Proses Pengolahan Tanduk untuk Pembuatan Sarung dan Gagang Rencong

(Sumber: Reza Sastra Wijaya, 2020)

Selain dengan menggunakan teknik pengecoran logam pembuatan rencong juga dapat dilakukan dengan cara menempa bilah rencong dengan memanaskan besi di atas bara. Kemudian besi yang telah dipanaskan hingga merah dan membara tersebut ditaruh di atas tatakan besi dan dipukul secaraberulang-ulang menggunakan palu sehingga bentuk bilah tersebut dapat dibentuk dengan mudah dan sesuai dengan hasil yang diinginkan. Sementara pembuatan gagang dimulai dari tahap pengolahan kayu dan tanduk. Pengolahan tanduk ini dimulai dengan tahapan pengapian atau pembakaran tanduk sehingga tanduk tersebut mudah untuk dibentuk dan dipotong-potong dengan bentuk-bentuk yang sesuai dengan yang diinginkan. tanduk diolah dan dijadikan dua komponen yakni komponen pada sarung dan komponen yang terdapat pada gagang.

Begitu juga dengan pengolahan kayu yang digunakan. Material kayu yang digunakan adalah kayu yang dipilih dari hutan dengan kualitas terbaik yakni kayu Kemuning dengan karakterkayu yang amat keras dan memiliki warna kuning, sehingga pada saat proses finishing kayu tersebut dapat dipoles dengan bentuk yang sangat licin dan mengkilap tanpa menggunakan material-material kimia seperti bahan finishing kayu melainkan dengan bahan-bahan tradisional seperti abu dapur dan dedauan. Kegunaan tanduk dan kayu pada gagang tidak dibuat secara terpisah melainkan digabung sehingga antara kayu dan tanduk saling menyambung dan membentuk suatu bentuk yang artistik sehingga mempercantik dan memperindah bentuk rencong tersebut.

Secara umum dapat disimpulkan bahwasanya pembuatan rencong ini dapat diurut dengan sistematis. dimulai dari pengumpulan bahan logamuntuk pembuatan material bilah pisau dan pengumpulan material kayu dan tanduk sebagai material gag ang dan sarung rencong. kemudian pengolahan masing-masing komponen ini dibuat di tempat yang terpisah dan ada juga yang membuat di tempat yang sama. komponen-komponen terpisah ini dibawa ke satu tempat
Gorga : Jurnal Seni Rupa

Volume 09 Nomor 02 Juli-Desember 2020

p-ISSN: 2301-5942 | e-ISSN: 2580-2380

untuk digabungkan menjadi kesatuan utuh rencong dan disinilah dilakukan tahap penggabungan dan tahap finishing sehingga rencong siap untuk di kemas atau dipas arkan dan dis tribusikan ke pada distributor rencong, dan pasar-pasar yang menyediakan souvenir Aceh, seperti pasar Penanyong di kota Banda Aceh.

Rencong merupakan senjata tradisional Aceh yang digunakan pada masa kesultanan Aceh yakni pada masa pemerintahan Sultan Ali Mughayat Syah yang merupakan Sultan Aceh pertama pada abad ke 16. Rencong pada masa ini memiliki peranan penting yang mana rencong ini merupakan simbol dari perjuang dan perlawana bangsa Aceh melawan para penjajah, Dimana pada zaman dahulu orang yang memiliki rencong memiliki bentuk rencong tersendiri baik dari bahan yang digunakan maupun dari bentuk rencong Aceh. Rencong juga di buat sesuai tahta tertentu seperti raja, sultan, para uleebalang (kepala arak).

Pada masa kesultanan Aceh, rencong biasanya digunakan pada saat acara upacara tertentu seperti dalam ritual peusijuk, meugang, tung dara baro dan dalam upacaraupacara penting yang bersifat upacara adat lainnya, dalam hal ini rencong digunakan sebagai atribut dalamberbusana adat dalam setiap upacara yang diselipkan pada pakaian adat. Selain itu saat ini rencong juga digunakan sebagai property pertunjukan seperti tari dan pertunjukan lainya. Untuk material rencong ini sendiri memiliki beberapa tingkatan yakni, untuk Sultan rencong terbuat dari bahan emas dan gading gajah sebagi gagang dan sarung yang berukiran ayat-ayat suci Al-Qur'an, sedangkan rencong lainny a bias anya terbuat dari perak, kuningan dan sebagian dengan besi putih. Bagi mas yarakat Aceh rencong adalah simbol perjuangan, simbol sebagai prajurit, simbol keberanian dan kegagahan orang Aceh. Bagi masyarakat Aceh pemagangan rencong itu sendiri secara psikologis dapat menin gkatkan keberanian dalammenghadapi musuh.

Perkembangan zaman turut menggerus dan merubah fungsi dari rencong ini sehingga rencong tidak lagi dibutuhkan sebagai senjata untuk berperang. namun rencong telah berubah fungsi menjadi warisan budaya yang memiliki pamorke banggaan rakyat Aceh. Oleh sebab itu rencong ini banyak diproduksi sebagai pajangan suvenir dan buah tangan bagi tamu kehormatan.

\section{2). Perkembangan Bentuk dan Fungsi Kerajinan Rencong di Desa Baet}

Anatomi rencong yang ada sekarang initidakjauh berubah dengan rencong yang telah dibuat pada zaman dahulu. Hany a s aja mengalami perubahan material utama yakni dari penggunaan material baja menjadi material besi putih bahkan material material besi yang mudah diolah seperti kuningan yang bertujuan hanya sebagai souvenir dan tidak 
digunakan sebagai senjata aktif. Selain materi logam, material-material lain yang dipergunakan masih menggunakan material sama seperti yang digunakan pada zaman dahulu yakni material tanduk kerbau dan kayu material sebagaibahan utamanya dalampembuatan gagang dan sarung rencong.

Namun pembuatan kerajinan rencong saat ini dengan mengunakan bahan tanduk kerbau dan kayu, tidak lagi menggunakan gading Gajah. Halini bertujuan agar keaslian rencong tetap dapat dipertahankan, Meskipun secara fungsinya sudah beralih yakni dari fungsi senjata menjadi fungsi komersial dalam bentuk souvenir. Rencong yang ada pada saat ini mengalami perkembangan yang cukup pesat. Hal ini ditandai oleh banyaknya peminat rencong dari berbagai daerah dipenjuru tanah air bahkan dari luar negeri. Selain itu rencong juga sudah memiliki perkembangan dari ornamen kreasi yang diterapkan pada gagang dan sarung rencong, ornamen-ornamen ini diambil dan dikreasikan sesuai dengan keinginan pelanggan.

Perkembangan bentuk (form) rencong di desa Baet, dapat dilihat dari bentuk rencong yang semakin bervariasi mulai dari bentuk dan ukuran rencong yang tidak lagi pada ukuran standar rencong itu sendiri. Secara ukuran rencong s aat ini memiliki ukuran $15 \mathrm{~cm}$ sampai dengan $2 \mathrm{M}$ sesuai dengan keinginan dari konsumen, selain bentuk proses pembuatan juga sudah sederhana dikarenakan fungsi dari rencong sendiri hanya sebatas hiasan bukan lagi sebagai senjata tajam. Faktor lain yang menyebabkan perkembangan bentuk rencong adalah meningkatnya kebutuhan pasar lokal maupun luar yang semakin hari memaks a masy arakat desa Baet harus lebih kreatif dalam memikat hati konsumenya sehingga inovasi-inovasi baru bermunculan mulai dari bentuk rencong yang dalamukuran kecil sampai ke bentuk rencong besar. Perkembang an lainnya yang dapat dilihat dari bentuk rencong adalah dengan diberikannya variasi pada gagang dan sarung dari rencong berupa penambahan warna dengan menggunakan kayu-kayu pilihan, sebagai warna alami pada rencong. Selain itu pembuatan bentukbentuk souvenir tetap meng adopsi bentuk rencong yang asli namun tidak meng gunakan bahan rencong pada umumna, yakni hanya menggunakan satu material saja seperti material bahan tulang dan bahan kayu yang berfungsi sebagai suvenir dan gantungan kunci.

Yudi juga menjelaskan desa Bait merupakan desa pertama yang memproduksi rencong di seluruh daerah Aceh, termasuk rencong pertama yang dibuat untuk Raja Aceh dalam melawan Belanda berasaldari desa Baet. meskipun pada perkembangannya rencong juga sudah diproduksi di berbagai daerah Aceh lainnya namun tetap memiliki perbedaan dari kehalusan bentuk dan pembuatan gagangnya (Wawancara, 26 Juli 2020).
Gorga : Jurnal Seni Rupa

Volume 09 Nomor 02 Juli-Desember 2020 p-ISSN: 2301-5942 | e-ISSN: 2580-2380

Rencong dalam perkembanganya saat ini digunakan sebagai cenderamata y ang sudah dapat dimiliki oleh siapa saja, berbeda pada zaman dahulu, dimana ada Batasan dan bentuk rencong tertentu hanya bisa dimiliki oleh para petinggi masyarakat Aceh. Pada perkembanganya bentuk rencong dikembangkan sebagai cendramata dan tidak lagi berfungsi sebagai senjata tajam. Dalam perkembanganya rencong saat ini sudah mengalami pergeseran nilai fungsional.

Pada dasarnya rencong merupakan salah satu senjata tradisional masyarakat Aceh, yang berfung si sebagai alat perang untuk melawan para penjajah yang masuk ke wilayah Aceh. Seiring perkembangan zaman kini rencong mulai beralih fungsidari fungsi senjata tajam ke fungsi lainya yakni sebagai aksesoris pakaian adat, tarian khas Aceh dan cendra mata seperti y ang diproduksi di des a Baet masjid. Selain itu akses oris rencong juga dapat dimiliki oleh siapa saja yang berkunjung ke Aceh khususnya di daerah Aceh Besar. Dahulunya rencong juga memiliki fungsi sebagai penandabagi masyarakat Aceh, dimanapada dahulunyatidak semua orang bisa memakai rencong, orang yang memakai senjata rencong hanya kaum elit kerajan. Berbeda halnya dengan sekarang dimana rencong dapat dimiliki oleh siapa saja.

\section{KESIMPULAN DAN SARAN \\ 1.Kesimpulan}

Rencong merupakan senjata tradisional mas yarakat Aceh yang harus terus dilestarikan dan dijaga, sebagai warisan yang mengangkat identitas masyarakat Aceh. Salah satunya bentuk pelesatarian budaya yang dilakukan oleh mas yarakat Aceh khususnya mas yarakat desa Baet adalah dengan terus mempertahankan dan memproduksi kerajinan rencong, sehingga keberadaanya rencong terus menjadi bagian dalam kehidupan masyarakat. Perkembangan bentuk kerajinan rencong di desa Baet Kecamatan Sukamakmur kabupaten Aceh Besar berada pada perkembangan bahan yang digunakan dalam pembuatan rencong, perkembangan pada ukuran pembuatan rencong dan perkembangan fungsi rencong dalam kehidupan masyarakat. Secara fungsi rencong berfungsi sebagai senjata tajamyang digunakan oleh para pejuang Acehuntuk melawan para penjajah yang masuk ke daerah Aceh. Berbeda halnya dengan saat sekarang ini dimana rencong berfungsi sebagai souvenir, oleh-oleh saat berkunjung ke daerah Aceh, selain itu rencong saat ini juga digunakan sebagai pelengkap dalampakaian ad at dan sebag ai properti pertunjukan.

\section{Saran}

Semoga dengan adanya penelitian ini mampu memberikan kontribusi terhadap masyarakat Aceh, khususnya masyarakat desa Baet agar lebih dikenal lagi diseluruh 


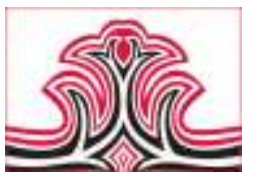

lapisan masyarakat, baik masyarakat lokal maupun masyarakat luar. Selain itu dengan adanya penelitian ini juga diharapkan bisa menjadi reverensi atau sumber bacaan bagipenelitian selanjutnya dalammengkaji perkembangan rencong dimasa yang akan datang. Untuk pemerintah daerah Aceh khususnya Aceh Besar sekiranya dapat memberikan perhatian khusus untuk peningkatan dan kebertahanan para pengrajin rencong di desa Baet Aceh Besar, selain itu juga pemerintah harus lebih giat dalam mempromosikan kerajinan rencong ke para tamu yang datang ke daerah Aceh.

itian yang dilangsungkan sebagai dasar upaya dukungan terhadap kampanye sustainable fashion atau zero waste fashion dengan memfokuskan terhadap potensi penggunaan kain rayon sebagai material mentah utama yang diolah kembali dengan teknik eco printing dan pewarnaan alam ini merupakan satu dari beragamcara yang masih dapat dikembangkan kembali untuk mendukung kelangsungan kampanye tersebut, ragam eksplorasi dalampros es ekperimen mas ih dapat terus dilakukan untuk mendapatkan hasil yang lebih bervariasi dan menarik. Pemerintah pula dapat memberikan banyak program dalam mendukung kegiatan sustainability di berbagai bidang, khususnya dalam indus tri teks til dan fashion dengan mengadakan sosialis asi berupa workshop yang dapat diikuti oleh masyarakat umum baik yang bergelut didalam bidang tekstil, garmen dan fashion dan yang memiliki ketertarikan dan mendukung manfaat dari programini. Hal tersebut juga dapat dihibahkan kepada fakultas/ program studi kriya tekstil dan fashion di Indonesia untuk menjadi pilar dalam menjalankan program ters ebut sebagai wujud peng abdian kepada mas yarakat.

\section{DAFTAR RUJUKAN}

Feldman, Edmund Burke. (1967). Art Is Image and Ide a atau Seni Sebagai Wujud dan Gagasan. Terjemahan Sp Gustami, 1991. ISI Yogyakarta: Yogyakarta.

Dharsono, Sony Kartike. (2016). Kreasi Artistik, Citra Sain, Bandung.

Ratna, Kutha Nyoman. (2010). Metodologi Penelitian, Pustaka Belajar, Yogyakarta.

Rohendi, Rohidi Tjetjep. (2011). Metodologi

Penelitian Seni, Cipta Prima Nusantara, Semarang.

Said, Muhammad. (1981). Aceh Sepanjang Abad. Waspada, Universitas Michigan.

Sri, W aryanti. (2013). Makna Rencong Bagi Ureueng Aceh, Patanjala, Bandung. 